\title{
IMMUNOLOGICAL COMPARISON OF THE NADH:NITRATE REDUCTASE FROM DIFFERENT CUCUMBER TISSUES
}

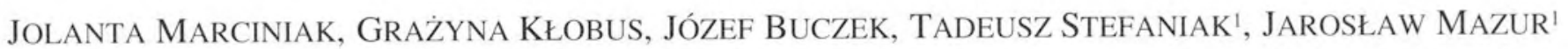 \\ Plant Physiology Department, Institute of Botany, Wrocław University, \\ Kanonia 6/8, 50-328 Wrocław, Poland. \\ 'Veterinary Medicine and Immunology Department, \\ University of Agriculture, Norwida 31, 50-375 Wrocław, Poland. \\ (Received: December 14, 1994. Accepted: June 30, 1995)
}

\begin{abstract}
Soluble nitrate reductase from cucumber roots (Cucumis sativus L.) was isolated and purified with blue-Sepharose 4B. Specific antibodies against the NR protein were raised by immunization of a goat. Using polyclonal antibodies anti-NR properties of the nitrate reductase from various cucumber tissues were examined. Experiments showed difference in immunological properties of nitrate reductase (NR) from cotyledon roots and leaves.
\end{abstract}

KEY WORDS: nitrate reductase, antibody, dot-blot, immunological assays, Cucumis sativus.

\section{INTRODUCTION}

Most of the photosynthetic organisms require nitrate as their main inorganic source of nitrogen. Nitrate absorbed by the plant roots can be reduced in both, root and leaf tissues (Jolly and Tolbert 1978, Redinbough and Campbell 1981). The first rate-controlling step of $\mathrm{NO}_{3}$ assimilation in higher plants is catalyzed by nitrate reductase (NR, EC.1.6.6.1), which properties have been subject of a number of reviews (Beevers and Hageman 1980, Campbell and Kinghorn 1990, Caboche and Rouze 1990). This multicenter enzyme reduces nitrate to nitrite using NADH as its natural electron donor.

Over the past 40 years, since the discovery of NR by Evans and Nason (1953), considerable attention has been focused on the method for isolation and purification of this

\section{List of abbreviations:}

BSA - bovine serum albumine,

$\mathrm{CNBr}$ - bromocyjan,

DTT - dithiotreitol,

EDTA - etylenediaminetetraacetic acid,

ELISA - enzyme linked immunosorbent assay,

FAD - flavin adenine dinucleotide,

IgG - immunoglobulin,

MVH - methylviologen (reduced form),

NADH - nicotinamide adenine dinucleotide (reduced form),

NR - nitrate reductase,

PBS - phosphate buffered saline,

PMSF - phenylmethylsulfonyl fluoride,

PVPP - polivinylopolypirolidone enzyme. Since NR is a highly efficient catalyst, tightly regulated in plant tissues, it is not present in large quantities (Beevers and Hageman 1983, Campbell and Smarelli 1986). Moreover, NR is highly labile protein and consequently, difficult to purify. Very good results in purification of higher plant NADH:NR was achieved when affinity chromatography with activated Sepharose was used (Sherrard and Dalling 1979, Nakagawa et al. 1985, Nakamura and Ikawa 1993). This method enabled to obtain the pure enzyme through a specific elution with NADH. In protein characterization studies, the immunological techniques are important tools. Since nitrate reductase has been found as a good antigen, specific antibodies against the protein of NR from various higher plants were raised (Snapp et al. 1984, Hyde et al. 1989). Immunoassays were used to compare the nitrate reductase from different tissues (Nakagawa et al. 1986) and species (Notton et al. 1983, Cherel et al. 1986).

In the present work we purified the soluble nitrate reductase from cucumber roots and prepared antibodies against it to investigate the molecular properties of the enzyme from different tissues of cucumber seedlings.

\section{MATERIAL AND METHODS}

\section{Plant material.}

Cucumber seeds (Cucumis sativus L. var. Wisconsin) after germination were cultivated hydroponically for 5 or 10 days in $\mathrm{N}$-free solution, as described previously (Buczek and Marciniak 1990). Nitrate reductase was induced by transferring the seedlings into one-third strength Hoagland solution. 


\section{Enzyme extraction.}

Crude extract was prepared by grinding of roots in a chilled mortar with the extraction buffer containing $50 \mathrm{mM} \mathrm{K}$-phosphate $(\mathrm{pH} 7.5), 1 \mathrm{mM}$ EDTA, $1 \mathrm{mM}$ DTT, $1 \mathrm{mM}$ PMSF $10 \%$ glicerol and $0.5 \%$ PVPP. The extract was filtered through four layers of cheesecloth and centrifuged at $20000 \mathrm{~g}$ for 20 min. The supernatant was used as enzyme source.

\section{Enzyme purification.}

\section{Precipitation with ammonium sulfate.}

Solid ammonium sulfate was slowly added to the supernatant with continuous stirring. The fraction precipitated between $20-50 \%$ saturation was collected by centrifugation at $20000 \mathrm{~g}$ for $10 \mathrm{~min}$ and dissolved in $10 \mathrm{mM} \mathrm{K}$-phosphate (pH 7.5) containing $1 \mathrm{mM}$ EDTA, $1 \mathrm{mM}$ DTT and $1 \mathrm{mM}$ PMSF.

\section{Affinity chromatography.}

a.) Cyanogen bromide method of Sepharose $4 \mathrm{~B}$ activation and coupling of the ligand (according to Sherrard and Dalling 1979, with some modifications).

The swollen Sepharose $4 \mathrm{~B}\left(100 \mathrm{~cm}^{3}\right)$ washed with 2000 $\mathrm{cm}^{3}$ of distilled water by vacuum filtration was suspended in $200 \mathrm{~cm}^{3}$ of $2 \mathrm{M} \mathrm{Na}_{2} \mathrm{CO}_{3}$. The slurry was slowly stirred and 20 $\mathrm{cm}^{3}$ of $\mathrm{CNBr}$ dissolved in acetonitrile $\left(\mathrm{g}\right.$ per $\mathrm{cm}^{3}$ ) was added. During activation $\mathrm{pH}$ of the slurry was near 11. After 3 minutes the activated gel was washed with $1000 \mathrm{~cm}^{3}$ of $0.1 \mathrm{M}$ carbonate buffer ( $\mathrm{pH} \mathrm{9.5)} \mathrm{and} \mathrm{immediately} \mathrm{transferred} \mathrm{to} \mathrm{a} \mathrm{li-}$ gand solution. Dextran blue $2000(2 \mathrm{~g})$ dissolved in $200 \mathrm{~cm}^{3}$

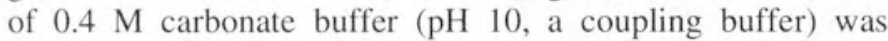
combined with CNBr-Sepharose $4 \mathrm{~B}$ for 18 hs in $4^{\circ} \mathrm{C}$. Noncoupled dye was removed with coupling buffer and the dye slurry was suspended in $0.1 \mathrm{M}$ Tris- $\mathrm{HCl}$ buffer $(\mathrm{pH} 8.0)$ to block an excess of active groups. After 1 hour the gel was transferred onto coarse disk sinterred glass funnel and rinsed out as follows with $500 \mathrm{~cm}^{3}$ of $0.1 \mathrm{M}$ citric acid- $\mathrm{NaOH}$ and

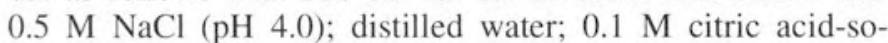
dium citrate and $0.5 \mathrm{M} \mathrm{NaCl}(\mathrm{pH} 8.0)$; distilled water. Washing procedure was repeated at least three times. Finally, the slurry was suspended in $0.05 \mathrm{M} \mathrm{K}$-phosphate buffer ( $\mathrm{pH} 7.5$ ). b.) Affinity chromatography on blue-dextran $\mathrm{CNBr}$ activated Sepharose 4B (chromatography was made by modification Redinbough's and Campbell's method 1981).

The ammonium precipitated fraction was loaded immediately onto Sepharose 4B column $(6 \times 2 \mathrm{~cm})$ equilibrated with 0.05 M K-phosphate (pH 7.5), 1 mM EDTA, 1mM DTT and $20 \mu \mathrm{M}$ FAD (buffer A). In some experiments the crude extract $\left(125 \mathrm{~cm}^{3}\right)$ was slowly stirred with $10 \mathrm{~cm}^{3}$ of blue Sepharose in buffer A. After $30 \mathrm{~min}$, the blue Sepharose was collected by vacuum filtration and washed with buffer A without FAD, to the moment when $\mathrm{A}_{280}$ was 0. Then Sepharose was suspended in about $30 \mathrm{~cm}^{3}$ of buffer $\mathrm{A}$ and packed onto $2 \mathrm{~cm}$ diameter column. Nitrate reductase was eluted from the gel with $70 \mathrm{~cm}^{3}$ of buffer A containing $100 \mu \mathrm{M} \mathrm{NADH}$. The flow rate during loading and elution was approximately $1 \mathrm{~cm}^{3}$ per minute. The level of NADH was spectrophotometrically controlled at $340 \mathrm{~nm}$. Fractions $\left(3 \mathrm{~cm}^{3}\right)$ were collected to the tubes containing $50 \mu \mathrm{l}$ of $0.65 \mathrm{M} \mathrm{KNO}_{3}$ and the activity of NR was determined. Fractions with the highest activity of nitrate reductase were combined, lyophilized and stored at $-20^{\circ} \mathrm{C}$.

\section{Nitrate reductase assays.}

Total NADH:NR (EC 1.6.6.1) activity was examined in crude extract and in fractions collected from Sepharose. The incubation medium $\left(1 \mathrm{~cm}^{3}\right)$ contained $25 \mathrm{mM} \mathrm{K}$-phosphate buffer ( $\mathrm{pH} 7.5$ ), $10 \mathrm{mM} \mathrm{KNO}_{3}, 0.25 \mathrm{mM} \mathrm{NADH}$ and enzyme. After incubation $\left(30 \mathrm{~min}\right.$ at $27^{\circ} \mathrm{C}$ ) zinc-acetate was added to stop the reaction and mixture was centrifuged. In supernatant nitrite was determined colorimetrically at $540 \mathrm{~nm}$ (Sanderson and Cocking 1964).

\section{Protein determination.}

Protein was determined according to the method of Bradford et al. (1972) using BSA as a standard.

\section{Electrophoresis.}

Poliacrylamide gel electrophoresis was carried out according to Laemmli (1970). Concentration of the poliacrylamide native gel was $7 \%$. The gel was stained with Coomassie Blue $\mathrm{R}-250$ to protein detection. Visualization of NR activity in the gel was provided according to Heath-Pagliuso et al. (1984).

\section{Preparation of antiserum.}

The pure, lyophilized protein of NR was used to raise a crude antiserum. Equal volumes of the enzyme $\left(0.5 \mathrm{~cm}^{3}\right.$ containing $100 \mu \mathrm{g}$ of protein) and Freund's adjuvant were emulsified and then injected $\left(0.2 \mathrm{~cm}^{3}\right)$ intradermally into the goat every two weeks. The level of goat IgG anti-NR was controlled at regular intervals by standard method of ELISA. After 12 weeks the crude serum was collected by blood centrifugation.

\section{Dot-blot assays.}

Immunoblotting was carried out at room temperature. The samples $(5 \mu \mathrm{l})$ were loaded onto a nitrocellulose sheet, airdried and incubated $1 \mathrm{~h}$ with blocking solution containing 0.05 M K-phosphate buffer ( $\mathrm{pH} 7.5$ ) with $0.9 \% \mathrm{NaCl}$ [PBS], $1 \%$ BSA, $1 \%$ casein, $2 \%$ PVP and $0.05 \%$ Tween 20 . The nitrocellulose sheet was transferred to PBS containing goat antiNR serum (1:10). After $1 \mathrm{~h}$ the blot was washed three times with PBS and incubated for 1 hour with horseradish-peroxidase conjugated goat anti-goat IgG diluted 1:1000 in PBS. AntiNR cross-reactive dots were detected by development of the dye with the mixture of 4 chloro-1-naphthol in $2 \mathrm{~cm}^{3}$ of methanol and $6 \mu \mathrm{l}$ of $30 \% \mathrm{H}_{2} \mathrm{O}_{2}$ in $8 \mathrm{~cm}^{3}$ of PBS.

\section{Antiserum titration.}

Preimmune control serum $(10,50$ and $100 \mu \mathrm{l})$ or goat anti NR serum $(10,40$ and $80 \mu \mathrm{l})$ was added to $1 \mathrm{~cm}^{3}$ of crude enzymatic extract obtained from cucumber roots. Concentration of protein was $3 \mathrm{mg}$ per $\mathrm{cm}^{3}$ or $2 \mathrm{mg}$ per $\mathrm{cm}^{3}$ in serum and enzymatic extract, respectively. The samples were incubated for $1,5 \mathrm{~h}$ at $4^{\circ} \mathrm{C}$, centrifuged at $13000 \times \mathrm{g} 10 \mathrm{~min}$ and supernatant was used for determination of NR activity. All values selected for the figures and tables are representative for the results obtained in several (three to four) independent experiments.

\section{RESULTS AND DISCUSSION}

The pure, active nitrate reductase was isolated from cucumber roots using two steps purification. The first step was ammonium sulfate fractionation followed with an affinity chromatography with blue Sepharose (Table 1A and Table 1B). Finally, the nitrate reductase was purified 155 - fold with only $4 \%$ recovery and specific activity of 0.9 units per mg protein (Table 1A). When ammonium precipitation was omitted the recovery of enzyme activity increased to $10 \%$ 


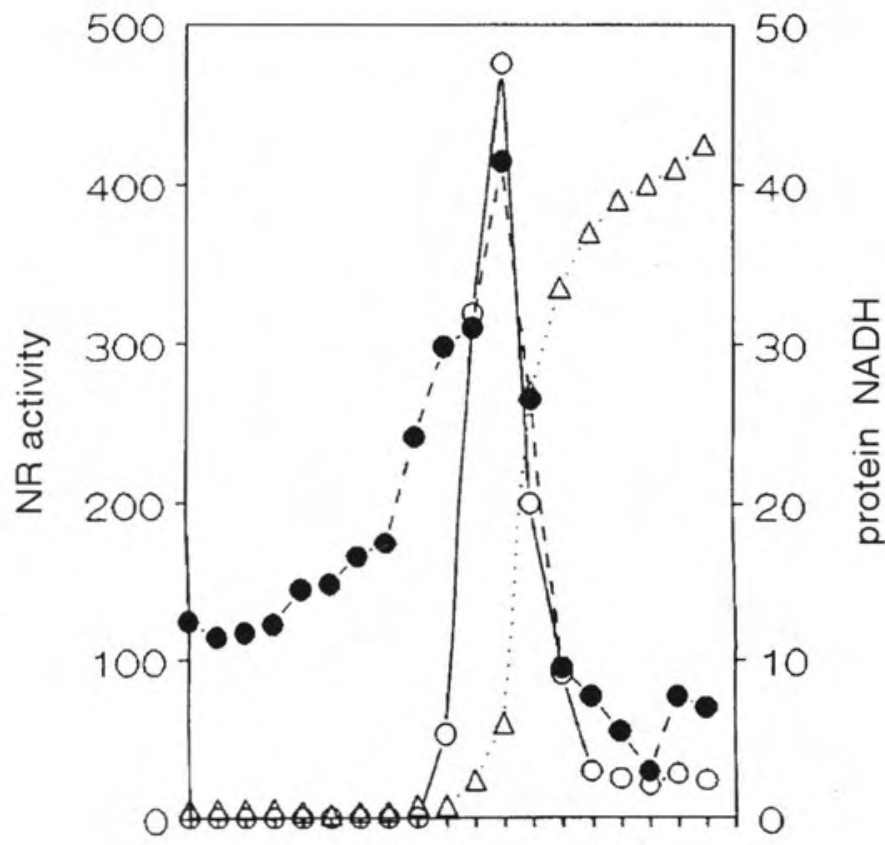

2468101214161820

fraction number
(Table 1B). For this reason in next experiments the crude extract from roots was mixed with blue Sepharose and then column was packed.

The elution profile of NR from the blue-Sepharose column is shown in Figure 1. The highest activity of the nitrate reductase was found in 4 fractions (fraction 10 to 14). Additionally, a large amount of protein was removed from column into the same fractions. It is worth of notice, that NR was eluted from the column always with a low concentration of NADH

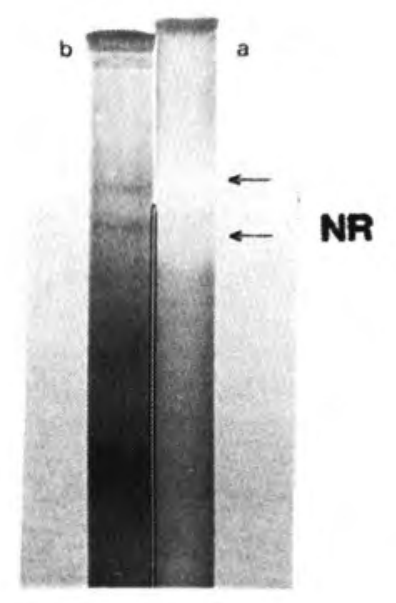

Fig. 2. Electrophoresis of the pure nitrate reductase after blue-Sepharose separation.

The fractions with high activity of NR eluted from blue-Sepharose were analyzed by PAGE (Laemmli 1970). After staining with Coomassie Blue R-250 two bands of the protein became visible (b). After developing NR activity according to Heath-Pagliuso et al. (1984) with $25 \%$ tetrazolinum red, two bands of NR were visible (a).
Fig. 1. Separation of the soluble NR by chromatography on blue Sepharose 4B.

- o - NR activity $\left(\mu \mathrm{mol} \mathrm{NO} \mathrm{NO}_{3}\right.$,

- - protein $(\mu \mathrm{g})$,

$-\Delta-\mathrm{NADH}(\mu \mathrm{mol})$

The crude enzymatic extract was loaded after centrifugation onto blue-Sepharose column. NR was removed with elution buffer containing $100 \mu \mathrm{M}$ NADH $\left(3 \mathrm{~cm}^{3}\right.$ fractions). The level of NADH was controlled spectrophotometrically at 340 $\mathrm{nm}$. Protein was determined according to Bradford (1976).
$(7 \mu \mathrm{M})$. Because of low protein recovery the fractions exhibiting the nitrate reductase activity were pooled and concentrated by lyophilization.

After subjection of the purified enzyme preparation to poliacrylamide disc gel electrophoresis under non-denaturing conditions, two protein bands appeared (Figure 2). Both bands were coincident with a specific staining for NR activity. It is suggested that during separation of the enzyme on blue Sepharose the most impurity have been lost.

The lyofilized samples of the pure enzyme were dissolved and used to immunization of the goat. The immunological answer was controlled by ELISA and results were summarized in Figure 3.

The amount of the polyclonal antibodies anti-NR in goat serum was highest after the second injection and after the fourth one was sightly reduced. However, the whole amount of antibodies in comparison with the basic level ("0") was satisfactory. Antiserum efficiency (probably the mixture of $\mathrm{IgG}$ and slight amount of $\operatorname{IgM}$ ) was controlled by the dot-blot method on nitrocelullose paper (Figure 4) and by antiserum titration (Figure 5). After an immunochemical cross-reaction of antiNR IgG with the enzyme and goat IgG conjugated with peroxidase, we observed the appearance of dye dots on nitrocelullose paper. In titration experiments the activity of nitrate reductase from cucumber roots decreased after $1,5 \mathrm{~h}$ preincubation with polyclonal antibodies (anti-NR). Preimmune control serum had no effect on the enzyme activity (Figure 5). Results of dot-blot reaction and titration experiments confirmed the good affinity between the nitrate reductase and obtained antibodies. Polyclonal antibodies reacted not only with NR in crude extract but also with the pure enzyme.

Dot-blot technique was used to examine the immunological properties of NR from various cucumber tissues (Figure 6). We observed the positive reaction between goat NR-antibodies and crude extracts from roots, cotyledons and leaves of 


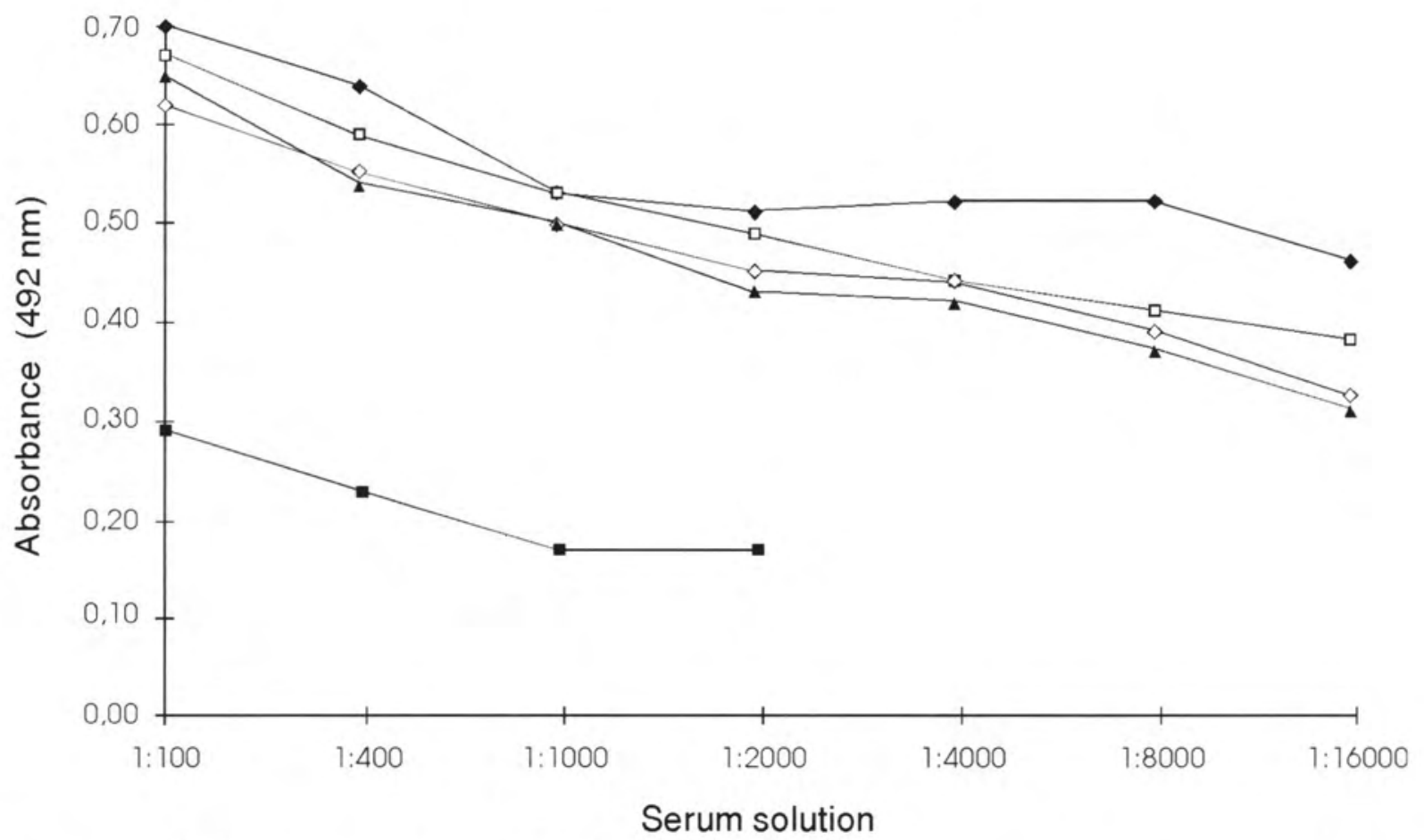

Fig. 3. Demonstration of the level polyclonal antibodies anti-NR in goat serum by ELISA.

- control serum (no immunized),

$-\neg-1^{\text {st }}$ injection,

$--2^{\text {nd }}$ injection,

$-\diamond-3^{\text {rd }}$ injection,

$-\boldsymbol{\Delta}-4^{\text {th }}$ injection,

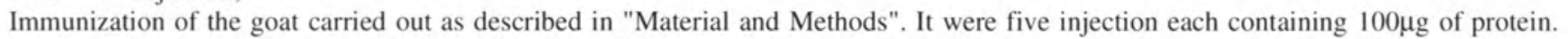
In regular intervals blood samples were collected and the level of anti-NR estimated by the standard method of ELISA.
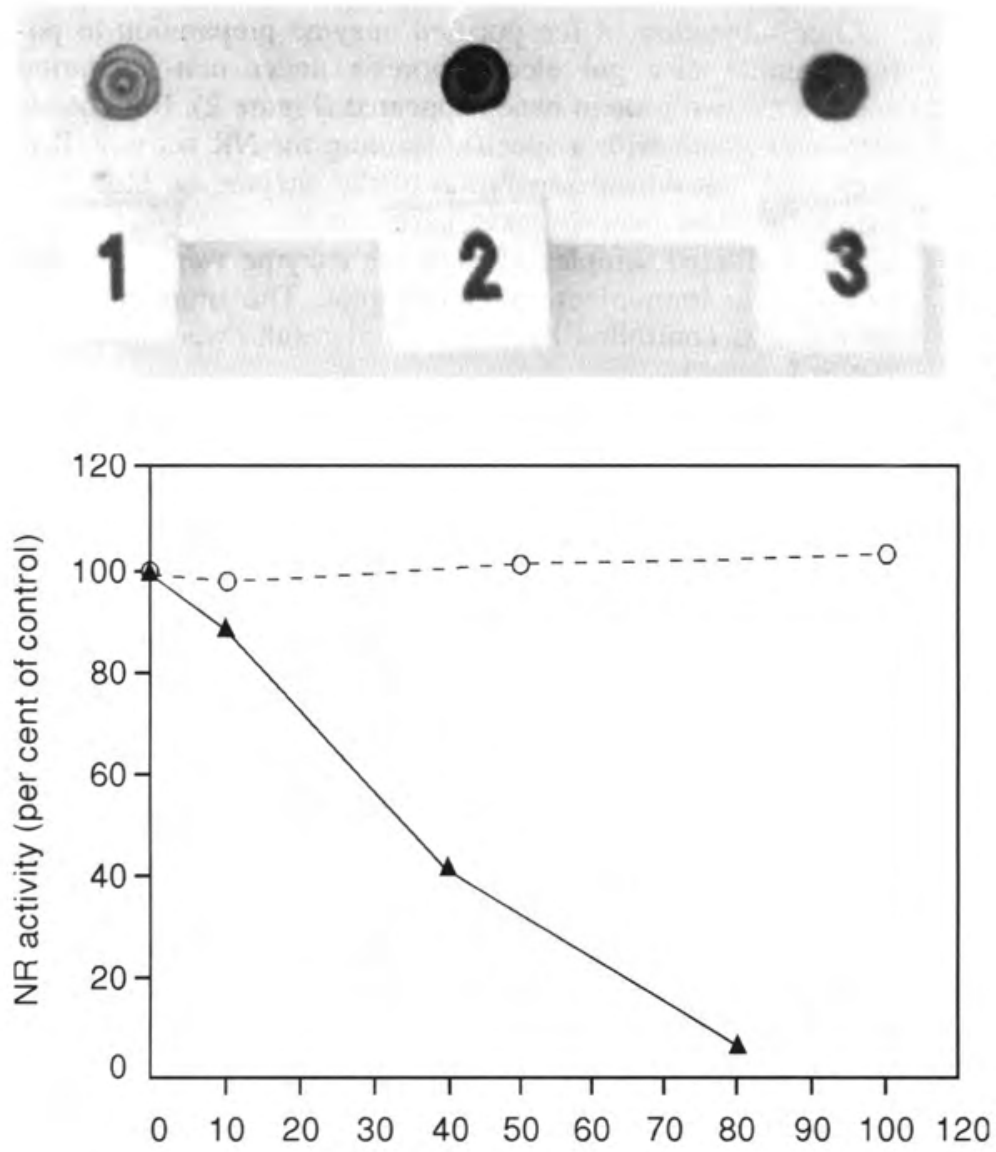

Amount of antiserum $(\mu \mathrm{l} / \mathrm{cm})$
Fig. 4. Test of cross-reactivity of the goat anti-NR.

Nitrate reductase was obtained from cucumber roots and purified as described in "Material and Methods". $5 \mu \mathrm{l}$ samples of lyophilized enzyme fraction (1), blue Sepharose fraction (2) and crude extract (3) were loaded onto nitrocellulose paper and labelled by goat anti-NR and then with anti-goat IgG conjugated with peroxidase.

Fig. 5. Titration of nitrate reductase by preimmune control and goat anti-NR sera.

Crude enzymatic extract from roots of the cucumber seedlings $\left(1 \mathrm{~cm}^{3}\right)$ was incubated $1,5 \mathrm{~h}$ in $4^{\circ} \mathrm{C}$ with preimmune serum (control $-\mathrm{O}-$ ) or goat anti-NR $(-\mathbf{\Delta}-)$ ). After centrifugation (13000 x g $\left.10 \mathrm{~min}^{-1}\right)$ an enzyme activity was estimated as described in "Materials and Methods". Initial enzyme activity $(100 \%)$ was $348 \mathrm{nmol} \mathrm{NO}_{2} \mathrm{x} \mathrm{g} \mathrm{g}^{-1} \mathrm{FW}$. 


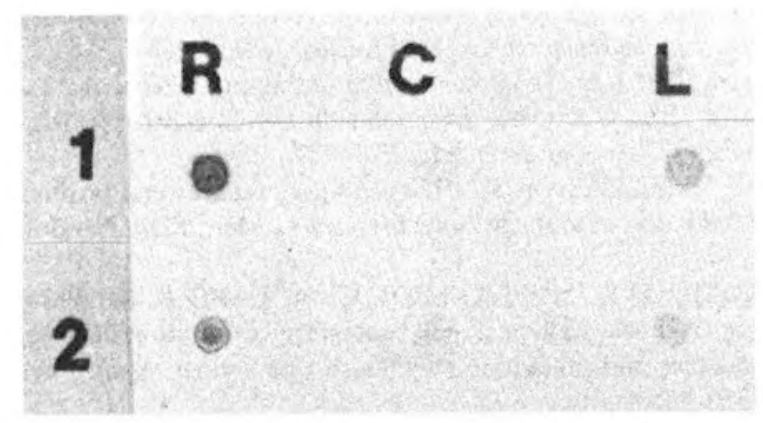

Fig. 6. Dot-blot assays nitrate reductase in crude extracts from cucumber root, cotyledon and leaf.

$5 \mu \mathrm{l}$ undiluted samples of crude enzymatic extracts from roots ( R), cotyledons (C) and leaves (L) (row 1) were loaded onto nitrocellulose paper. In row 2 each of the $5 \mu \mathrm{l}$ samples contains $10 \mu \mathrm{g}$ of protein. Dye dots were developed with 4 chloro-1-naphthol after staining with polyclonal anti-NR and goat anti-goat IgG conjugated with horseradish-peroxidase.

cucumber. These results indicate a similarity in antigenic sites of the nitrate reductase from different tissues. Also Sommers et al. (1983) tested NR from barley with Western-blot assay and showed that NR antibody from roots cross-reacted with NR from leaves. In our experiments different intensity of dye between dots in dot-blot assays was found. In row 2 (Fig. 5), when the amount of enzyme protein was the same in all dots, the dye reaction with cotyledon NR was slighter than with the other tissues.

After $1 \mathrm{~h}$ preincubation of polyclonal NR-antibodies at $4^{\circ} \mathrm{C}$ with crude extracts from all of the investigated tissues, differences in enzyme activity were observed (Table 2). With 1:100 dilution of antiserum, the activity of NR in roots and leaves was reduced by $30 \%$ and $45 \%$, respectively. The decrease of NR activity in the presence of antibody was demonstrated also by Ferrario et al (1983) for spinach nitrate reductase from both, root and leaf. However, these authors, basing on Ouchterlony test, suggested that the root and leaf NR of spinach was a different protein. On the other hand, Nakagawa et al. (1986) concluded that such result may be due to instability of the enzyme protein or properties of polyclonal antibodies. Our data have shown partial identity in immunological properties between the nitrate reductase protein in root and leaf tissues of cucumber seedlings. In contrast, the nitrate reductase of cotyledons demonstrated different properties from NR of roots and leaves. In the same dilution of antiserum $(1: 100)$ NR activity of cotyledons was stimulated whereas the enzymes from roots and leaves were inhibited. In the presence of NR antibody the nitrate reductase from cotyledon shows also a various intensity in dot-blot cross-reaction.

For this reason we suggest, that the nitrate reductase in storage tissues like cotyledons has slightly different molecular properties as compared with enzymes of other plant tissues.

TABLE 1. Purification of the nitrate reductase from cucumber roots.

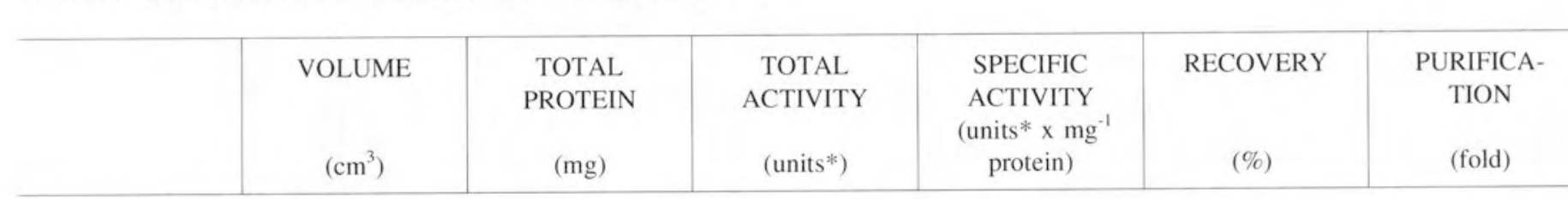

A.

\begin{tabular}{|c|c|c|c|c|c|c|}
\hline $\begin{array}{l}\text { CRUDE } \\
\text { EXTRACT }\end{array}$ & 200 & 102.300 & 0.660 & 0.006 & 100 & 1 \\
\hline $\begin{array}{l}\text { AMMONIUM } \\
\text { SULFATE }\end{array}$ & 10 & 59.440 & 0.261 & 0.044 & 67 & 68 \\
\hline $\begin{array}{l}\text { BLUE } \\
\text { SEPHAROSE }\end{array}$ & 6 & 0.034 & 0.027 & 0.900 & 4 & 155 \\
\hline \multicolumn{7}{|c|}{ B. } \\
\hline $\begin{array}{l}\text { CRUDE } \\
\text { EXTRACT }\end{array}$ & 200 & 124.000 & 0.724 & 0.006 & 100 & 1 \\
\hline $\begin{array}{l}\text { BLUE } \\
\text { SEPHAROSE }\end{array}$ & 6 & 0.084 & 0.071 & 0.845 & 10 & 140 \\
\hline
\end{tabular}

Units* - $\mu$ mole $\mathrm{NO}_{2} \times \min ^{-1}$

$25 \mathrm{~g}$ of cucumber roots were ground in a chilled mortar with extraction buffer (50 mM K-phosphate, $1 \mathrm{mM}$ EDTA, $1 \mathrm{mM} \mathrm{DTT}, 1 \mathrm{mM}$ PMSF, $10 \%$ glicerol, $0.5 \%$ PVPP; pH 7.5) and centrifuged at $20000 \mathrm{~g}$ for $20 \mathrm{~min}$. The supernatant named crude extract was used as the enzyme source. The ammonium sulfate precipitate $(20 \%-50 \%)$ of the NR was loaded onto blue Sepharose column $\left(6 \times 2 \mathrm{~cm}^{3}\right)$ as described in "Material and Methods". 
TABLE 2. Preincubation of cucumber NADH:NR with goat polyclonal anibodies anti-NR.

\begin{tabular}{|c|c|c|c|}
\hline \multirow{2}{*}{$\begin{array}{c}\text { SERUM } \\
\text { DILUTION }\end{array}$} & \multicolumn{3}{|c|}{ NR activity $\left(\mu \mathrm{mol} \mathrm{NO}_{3}^{-} \times \mathrm{g} \mathrm{FW} \times \mathrm{h}^{-1}\right)$} \\
\hline & Root & Cotyledon & Leaf \\
\hline$\ldots$ & 0.080 & 0.132 & 0.648 \\
\hline $1: 100$ & 0.057 & 0.202 & 0.360 \\
\hline
\end{tabular}

Crude enzymatic extracts from root, cotyledon and leaf were preincubated $1 \mathrm{~h}$ at $4^{\circ} \mathrm{C}$ without (control) or with 1:100 dilution of anti- NR, centrifuged (13 $000 \times \mathrm{g} 10 \mathrm{~min})$ and then activity of the enzyme was examined as described in "Material and Methods".

This experiment was repeated three times yielding similar results.

\section{ACKNOWLEDGEMENTS}

This study was supported by grant from The Polish Comittee for Scientific Research (KBN, 393/PO4/95/08).

\section{LITERATURE CITED}

BEEVERS L., HAGEMAN R.H. 1980. Nitrate and nitrite reduction. In: The Biochemistry of Plants. Miflin B.J. ed., New York: Academic Press, Vol.5: 115-168

BEEVERS L., HAGEMAN R.H. 1983. Uptake and reduction of nitrate: Bacteria and Higher Plants. In: Encyclopedia of Plant Physiology. New Series. V 15A ed. Lauchli A., Bieleski R.L., Springer Verlag, Berlin: 351-357

BRADFORD M.M. 1976. A rapid and sensitive method for the quantitation of microgram quantities of protein utilizing the principle of protein-dye binding. Anal. Biochem. 72: 278-293.

BUCZEK J., MARCINIAK J. 1990. The effect of sodium orthovanadate on nitrate reductase activity and nitrate absorption in cucumber seedlings. Acta Physiol. Plantarum 12: 25-33

CABOCHE M., ROUZE P. 1990. Nitrate reductase: a target for molecular and cellular studies in higher plants. Trends in Gen. 6: 187-192

CAMPBELL W. H., KINGHORN J.R. 1990. Functional domains of assimilatory nitrate reductases and nitrite reductases. Trends in Biochem. 15 (8): 315-319.

CAMPBELL W.H., SMARELLI JR, J. 1986. Nitrate reductase biochemistry and regulation. In: Biochemical Basis of Plant Breeding (C. Neyra, ed.) Vol. II pp. 1-39. CRC Press, Boca Raton, FL. ISBN 08493-5742-X

CHEREL I., MARION-POLL A., MEYER C., ROUZE P. 1983. Immunological comparison of nitrate reductases of different plant species using monoclonal antibodies. Plant Physiol. 81: 376-378
EVANS H. I., NASON A. 1953. Piridine nucleotide nitrate reductase from extracts of higher plants. Plant Physiol. 28:233-254

FERRARIO S., HIREL B., GADAL P. 1983. Immunochemical characterization of nitrate reductase from spinach leaves and roots. Biochem. Biophys. Res. Commun. 113: 733-737

HARPER J.E., HAGEMAN R.H. 1972. Canopy and seasonal profiles of nitrate reductase in soybeans Glycine max. L. Merr. Plant Physiol. 49: $146-154$

HEATH-PAGLIUSO S., HUFFAKER R. C., ALLARD R. W. 1984. Inheritance of nitrite reductase and regulation of nitrate reductase, nitrite reductase and glutamine synthetase isoenzymes. Plant Physiol. 76: 353-358

HYDE G.E., WILBERDING J.A., MEYER A.L., CAMPBELL E.R., CAMPBELL W.H. 1989. Monoclonal antibody- based immunoaffinity chromatography for purifying corn and squash NADH: nitrate reductases. Evidence for an interchain disulfite bond in nitrate reductase. Plant Mol. BIOL.13: 233-246

JOLLY S. O., TOLBERT N. E. 1978. NADH-nitrate reductase inhibitor from soybean leaves. Plant Physiol. 62: 197-203

KLEINHOFS A., NARAYANAN K.R., SOMERS D.A., KUO T.M., WARNER R.L., 1986 Immunochemical Methods for Higher Plant Nitrate Reductase. In Immunology in Plant Sciences; edited by Linskens H.F., Jackson J.F. Springer Verlag, Berlin; p: 190-209

LAEMMLI U.K. 1970. Cleavage of structural proteins during the assembly of the head of bacteriophage T4. Nature 227: 680-689

NAKAGAWA H., YONEMURA Y., YAMAMOTO H. SATO T., OGURA N., SATO R. 1985. Spinach nitrate reductase: purification, molecular weight and subunit composition. Plant Physiol. 77: 124128

NAKAGAWA H., YAMAGISHI K., YAMASHITA N., SATO T., OGURA N., OAKS A. 1986. Immunological characterization of nitrate reductase in different tissues of spinach seedlings. Plant Cell Physiol. 27(4): 627-633

NAKAMURA Y., TOMOYOSHI I. 1993. Purification and properties of NADH: nitrate reductase from the red alga Porphyra yezoensis. Plant Cell Physiol. 34(8): 1239-1249

NOTTON B.A., FIDO R.J., GALFRE G. 1985. Monoclonal antibodies to a higher-plant nitrate reductase: differential inhibition of enzyme activities. Planta 165: 114-119

REDINBAUGH M.G., CAMPBELL W.H. 1981. Purification and characterization of $\mathrm{NAD}(\mathrm{P}) \mathrm{H}$ : nitrate reductase and $\mathrm{NADH}$ : nitrate reductase from corn roots. Plant Physiol. 68: 115-120

SHERRARD J.H., DALLING M.J. 1979. In vitro stability of nitrate reductase from wheat leaves. I. Stability of highly purified enzyme and its component activities. Plant Physiol. 63: 346-353

SOMERS D., KUO T.M., KLEINHOFS A., WARNER R.L., OAKS A. 1983. Synthesis and degradation of barley nitrate reductase. Plant Physiol. 72: 949-952

SNAPP S., SOMERS D.A., WARNER R.L., KLEINHOFS A. 1984. Immunological comparisons of higher plant nitrate reductase. Plant Sci. Letters 36: 13-18

\section{IMMUNOLOGICZNE WŁAŚCIWOŚCI NADH:REDUKTAZY AZOTANOWEJ W RÓŻNYCH TKANKACH OGÓRKA}

\section{STRESZCZENIE}

Praca miała na celu otrzymanie przeciwciał skierowanych przeciwko reduktazie azotanowej (anty-NR) oraz sprawdzeniu ich interakcji z enzymem izolowanym z różnych tkanek ogórka. Cytosolową formę reduktazy azotanowej uzyskaną w wyniku ekstrakcji korzeni ogórka oczyszczono przez filtrację na żelu blueSepharose 4B. Elektroforeza przeprowadzona w warunkach niedenaturujących białka potwierdziła czystość preparatu, który został następnie użyty do immunizacji kozy. Otrzymane przeciwciała anty-NR testowano metodą ELISA, miareczkowaniem immunologicznym oraz dot-blot, a następnie wykorzystano do identyfikacji reduktazy azotanowej w różnych tkankach ogórka. W ekstraktach z korzeni i z liści zaobserwowano wyraźne hamowanie aktywności reduktazy azotanowej w obecności przeciwciał anty-NR. Podobnego efektu nie znaleziono dla ekstraktu enzymatycznego otrzymanego z liścieni. 